\section{US adopts new cancer policy}

NEW guidelines setting out a common framework for both the scientific assessment of potential carcinogens and the appropriate regulatory mechanisms were announced by the US Government last week. The guidelines, described as a "Government-wide cancer policy", were published by the regulatory council set up by President Carter last October to coordinate federal regulations in general. (See Nature 27 September 1979 p244).

On the scientific side, the council supports that view that animal tests are a valid method of determining whether a substance should be considered a potential carcinogen. It also says that a single animal test, if properly conducted, is sufficient to indicate "a potential risk to humans" for regulatory purposes - a view contested by the chemical industry in current debates over the proposals of the Occupational Safety and Health Administration to establish a "generic carcinogen policy".

Referring to claims that a single positive test is not enough, the council says that "'although the agencies should attempt to obtain additional data, they should not

\section{School for scandal?}

Soviet University admissions procedures are being circumvented by over-ambitious parents, Pravda alleged recently. The offenders, it claimed, are making use of their professional position or contacts to obtain their children a priority position on the placement lists.

Admission to Soviet Universities and other higher educational institutions is by competitive examination. However, even for those who have passed the examination, there may still not be enough places. Priority is therefore given to "front-rankers" from agriculture or industry, who are recommended and supported by their former place of work, to which it is assumed they will return.

This priority scheme is intended to provide Soviet production with the specialists it needs where and when it needs them. Modifications are made from time to time to meet specific demands. Thus the normal length of service needed for a "front-ranker's" place is two years. However, in April of this year, workers sponsored by the Ministry of Land Reclamation and Water Conservancy were exempted from any minimum length of service presumably due to pressing demands for graduates in that sector.

Although no less than four signatures and an official seal are needed on the "front-ranker's", sponsoring form, "crafty parents" says Pravda, are managing to equip their sons and daughters with false papers. Not surprisingly, those who graduate under such auspices are in no hurry to start working at the farms or enterprises which sponsored them. Not surprisingly, too, a take the risk involved inwaiting two to four years" to conduct further tests before taking action. At the same time, the council has gone some way to meeting industry's demands by caling on agencies to ensure that proposals for regulating carcinogens are accompanied by some form of risk assessment, including in particular determining how many people are exposed to the substance.

The council implies that economic considerations should be included, urging agencies to identify and consider the least costly and least disruptive course of action in planning cancer controls. It also says that agencies should consider "zero risk" bans in cases where the economic and social costs are considered minimal.

"This new policy will ensure that the various agencies will operate from the same scientific base in determining whether a compound is carcinogenic", Mr Doug Costle, chairman of the Regulatory Council and head of the Environmental Protection Agency, said in announcing the new guidelines.

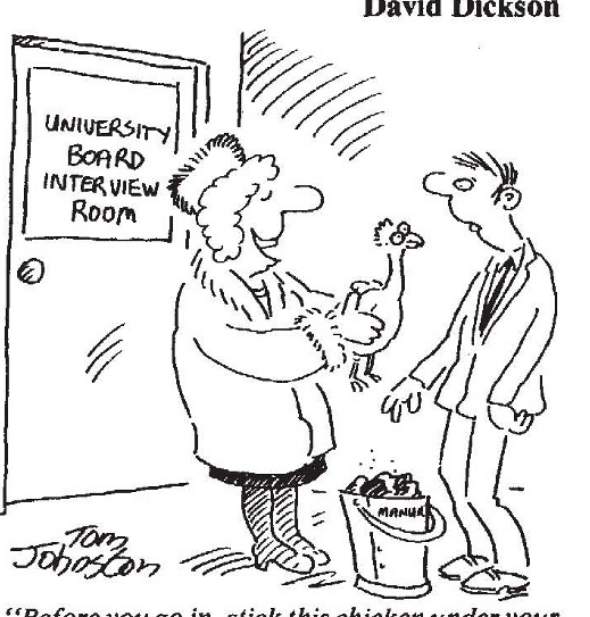

"Before you go in, stick this chicken under your arm and put some manure on your boots!"

number of the alleged "front rankers" have been abondoned in mid-course by their "sponsors" and have had to apply for state maintenance grants. Last July, the Central Committee of the Communist Party of the Soviet Union and the USSR Council of Ministers adopted a new decree on the "Further Development of Higher Education and Raising the Standard of Training of Specialist"'.

This provides for a new procedure of job allocation. By fixing a student's future job some two or three years before he or she graduates, the "output" of young scientists and technologists will, under the new system, become part of the normal Five Year Plan. Moreover, and particularly in the Far North and Siberia, measures are envisaged to retain the graduates in the area on a permanent basis.

Parents about to furnish their children with the certificates of Arctic lumberjacks would be well advised to think twice.

Vera Rich

\section{Superpower clash over test ban technology}

Delegates to the Geneva talks on a comprehensive test ban, currently nearing completion after almost two decades of negotiation, have reached an impasse over USSR demands that only Soviet equipment be used for the seismic monitoring on Soviet soil.

Until three months ago the US had assumed that the Soviet Union would permit the use of American detectors on its soil. Data from the detectors will be used to verify that seismic disturbances are the result of natural causes and not the undergound testing of nuclear weapons banned under the terms of the treaty.

However in June members of a US Congressional delegation visiting Moscow were told by Soviet officials that they would only permit Russian equipment to be used for this purpose - a condition which, in the eyes of the US politicians, would make the treaty unacceptable.

"We feel that it is essential to use US equipment to verify Soviet compliance; and that this point is so central that we cannot allow the test ban talks to proceed unless this is resolved," an aide to Representative Jack Kemp (Rep, New York), said recently.

State Department officials in Washington have been playing down the significance of the USSR demands, claiming that they see them as essentially a negotiating tactic which will be dropped in return for some concession from the US side. They have already rejected a request from Mr Kemp to cancel a visit by Soviet scientists last month to study US seismic technology - a visit which Mr Kemp described as "scientific espionage".

Furthermore seismic experts in the US feel the USSR would have little to gain from insisting on the use of their own equipment, since the US already possesses suitable equipment that can be bought "off the shelf"'; existing Russian equipment, it is claimed, lacks either the dynamic range or the precision of US seismic sensors.

Others involved in the negotiations, however, maintain that although relatively trivial, the issue is the sort which could seriously delay completion of the treaty, since no quick way out of the impasse can currently be seen. Any such delay could also effect the outcome of the second Nonproliferation Treaty Review Conference, which takes place next spring, and at which the non-nuclear powers will demand evidence from the nuclear powers of steps which have been taken to prevent escalation of the nuclear arms race.

Congressional aides said in Washington last week that they expect the issue of Soviet technology to be raised dring hearings on progress towards the test ban treaty due to be held by the House Armed Services Committee later in the autumn. $\square$ 